\title{
THE USE OF SYMPATHOMIMETIC AMINES IN THE TREATMENT OF SHOCK
}

\author{
James G. FoutKs, M.D.**
}

ANY discussion of drug therapy must necessarily revolve around two key points:

(1) What is the nature of the derangement to be treated? An understanding of the underlying pathogenesis of a diseased condition is essential to the definition of rational therapeutic objectives, that is, to a determination of what changes are required in order to correct the disordered function.

(2) To what extent can the therapeutic objectives thus defined be met by available pharmacological tools? An adequate understanding of the actions of a drug is necessary to know whether or not its use can be expected to aid in overcoming a particular pathological condition.

These principles may seem self-evident, and yet the breadth of our ignorance in both of these areas often requires us to rely on an empirical rather than a rational basis for therapy. The past five years have witnessed a number of important advances in the pharmacology of the sympathetic nervous system, with the introduction of agents whose place. in our therapeutic armamentarium is yet to be fully ascertained.

Among the sympathomimetic agents, nor-epinephrine has probably received more attention recently than any other. Actually, nor-epinephrine is not a new compound, its structure and basic actions having been known for nearly fifty years. Renewed interest in this compound has followed the relatively recent discovery that it is produced in the body and in fact is the major mediator of sympathetic nerve activity, comprising 80 per cent or more of the material released upon sympathetic nerve stimulation, the remainder consisting of epinephrine. Both of these substances are also present in the secretion of the adrenal medulla, but their relative proportions are reversed. The presence of 10 to 15 per cent of nor-epinephrine in extracts of the adrenal medulla was overlooked for many years, until its chemical separation became possible through the development of improved techniques.

While both epinephrine and nor-epinephrine are pressor compounds, their administration leading to a rise in blood pressure, nevertheless, there are a number of important differences in their cardiovascular actions. These can be appreciated most readily by a brief description of their effects on the heart and the peripheral circulation during continuous infusion.

The actions of epinephrine on peripheral vessels are mixed. While the vessels of the skin and the splanchnic bed are intensely constricted, this effect is more or less counterbalanced by dilatation of the vessels, of the skeletal muscles, so that the total peripheral resistance is relatively unchanged. The cardiac stimu-

\footnotetext{
*Presented at a meeting of the British Columbia Division, Canadian Anaesthetists' Society, January, 1954.

* Department of Pharmacology, University of British Columbia.
} 
lating actions are therefore primarily responsible for the pressor response which results when epinephrine is administered in this fashion. $f$

Nor-epinephrine (Arterenol, Levophed ${ }^{\circledR}$ ) while less potent in some of its vaso-constrictor actions, is more uniform. Its vaso-dilating actions are minor and its over-all effect is predominantly vaso-constriction with a rise in total peripheral resistance. Its cardiac stimulating action is almost as intense as that of epinephrine in isolated preparations, but in intact patients it is largely mitigated by reflexes arising from presso-receptors, which actually lead to a bradycardia by way of the vagal efferents to the heart. Thus the pressor response to norepinephrine is dominated by its peripheral vaso-constrictor actions.

These divergent actions serve to emphasize the point that the blood pressure is always the resultant of two components, cardiac action and peripheral vascular resistance, and an increase or decrease in either may be responsible for raising or lowering the blood pressure. This reciprocal relationship is further illustrated by the actions of isopropyl nor-epinephrine, a closely related amine with a marked vaso-depressor action. This compound causes a predominant vasodilatation with a marked fall in total peripheral resistance. Although its cardiac stimulating actions are, if anything, more intense than those of epinephrine and nor-epinephrine, and are unopposed by reflex modulation, the net effect is one of a substantial fall in blood pressure.

Current interest in sympathomimetic agents has been particularly aroused by the proposal that they may be efficacious in the treatment of shock. An evaluation of this possibility requires a brief consideration of some of the salient features of the various conditions grouped under the heading of shock. Broadly speaking, the principle feature which these conditions share in common is a persistent hypotension, the proximate cause of which may be either cardiac or peripheral. The obvious common-sense approach when faced with this situation, is to consider means of raising the blood pressure. The use of vaso-constricting drugs offers a convenient means to this end. However, this approach requires careful examination before it can be accepted as rational. Is the blood pressure a reliable measure of circulatory adequacy? Is hypotension, per se, the principle threat to life? The answer to this latter question must be qualified by saying that it depends on the degree. The crucial responsibility of the circulation is to provide oxygen and nutrition to the tissues. Its ability to do so is determined directly by the rate of flow of blood through the peripheral circulation, and while adequate flow depends upon a sufficient head of pressure, pressure is not the sole determinant of blood flow. The flow of blood through any tissue is determined by the resistance to flow offered by the tone of its small vessels as well as upon the head of pressure under which the blood is delivered. If vascular tone is reduced by vaso-dilatation, the pressure required to maintain a given flow through that tissue is also reduced. Actually, hypotension which is primarily peripheral in origin, that is, due to vaso-dilatation, is often well tolerated if not too drastic, even over fairly prolonged periods of time. For instance, high tran-

TThis description is based on the work of Goldenberg et al. (Amer. J. Med. 5:792 (1948)) who used moderate infusion rates. Larger amounts of epinephrine may constrict the vascular bed of skeletal muscle as well. 
section of the spinal cord in the cervical region gives rise to a condition known as spinal shock. This condition is characterized, among other things, by peripheral vaso-dilatation and a fall of mean blood pressure to levels of $30-40$ mm Hg., which may persist for twenty-four hours or longer with no permanent deleterious effect. Similar tolerance to prolonged hypotension experimentally is manifested by animals subjected to continuous stimulation of the carotid sinus. This is the type of hypotension which is deliberately produced under controlled conditions for certain surgical procedures by means of the administration of ganglionic blocking agents. In sympathectomy and in adrenergic blockade by drugs, a similar hypotension of peripheral origin is produced which can be well tolerated, in the supine position at least. The absence of reflex control in these conditions may jeopardize the cerebral circulation if the erect position is maintained. The advantage of ganglionic blockade is that a pressor response can still be produced and maintained by the more peripherally acting sympathomimetic amines. The same thing is true of the shock which may occur in spinal anaesthesia and one wonders whether this condition is truly as grave as it is sometimes considered to be.

In contrast to these examples are those cases of shock which follow a marked reduction in circulating blood volume, such as that which occurs following haemorrhage, burns, certain types of trauma, surgical procedures, and other related conditions. The loss of circulating fluid leads to poor venous return, poor cardiac filling, and a primary reduction in cardiac output. Compensatory reflex tachycardia commonly occurs, but the heart cannot put out more blood than is returned to it. Compensatory reflex vaso-constriction is fairly intense (although not maximal) and during the initial stages blood pressure is often maintained at fairly normal levels, while the rate of flow through the tissues is reduced as a result of the reduced cardiac output coupled with compensatory -vaso-constriction. If under these circumstances, blood pressures as low as $30-40 \mathrm{~mm} \mathrm{Hg}$. are allowed to persist for several hours, the shock becomes irreversible. While blood pressure may be restored temporarily, it cannot be maintained and the shock cannot be overcome, even after complete restoration of the lost circulating blood volume. Even the transfusion of relatively large amounts of blood is to no aqvail. We have already seen that in spinal shock such levels of pressure may be tolerated for long periods of time. It is not the low pressure which causes shock to become irreversible, but the reduced peripheral flow of blood through vital organs. The exact mechanism of irreversible shock is still not fully agreed upon, but the peripheral compensatory vaso-constriction appears to play an important role in its development. A number of investigators have reported that complete blockade of the sympathetic nervous system offers a highly significant degree of protection against the development of irreversible shock due to bleeding or trauma in experimental animals. Animals are subjected to shocking procedures and allowed to remain hypotensive for several hours, whereupon the volume of the circulating fluid is restored to normal levels. In control animals, survival rates range from 10 to 30 per cent. In animals pre-treated with sympathectomy, ganglionic or adrenergic blockade, and subjected to the same or equivalent procedures, recovery commonly runs as high as 80 to 90 per cent. It should be 
emphasized that in these experiments the shock is carried to the stage of irreversibility by maintaining a predetermined degree of hypotension. Animals subjected to adrenergic blockade reach this point with a smaller degree of -blood loss than do untreated animals. But untreated animals will survive a degree of blood loss greater than that which can be tolerated by animals subjected to adrenergic blockade. + Adrenergic blockade is not of therapeutic value in animals already carried to the irreversible stage of haemorrhagic shock. The point to be emphasized is that it is not the hypotension which leads to irreversibility, but the reduced flow of blood through vital tissues.

A considerable amount of experimental evidence has now accumulated which indicates that the release of ferritin (so-called VDM), especially by the anoxic liver, may play an important role in an explanation of these findings. This substance appears in the blood stream at about the time that shock becomes irreversible, and the liver loses its capacity to inactivate this material. Arterialization of the portal vein to the liver decreases the mortality of shock procedures. In animals pre-treated with sympathetic blockade,/VDM does not appear in the blood during the maintenance of a degree of hypotension which would otherwise lead to irreversible shock, and the liver retains its capacity to inactivate this material. VDM acts primarily to dilate capillary beds, and to render them unresponsive. The dilated beds lead to pooling of the blood, and the reservoir thus created may soak up large quantities of transfused blood and render the restoration of effective circulating blood volume exceedingly difficult to accomplish. Capillary anoxia may lead to further fluid loss directly into the tissues. In shock, hepatic blood flow is substantially reduced and when the irreversible stage is reached, the resistance to flow in the hepatic bed remains high in spite of restoration of normal circulating blood volume.

These facts force us to recognize that the rational therapeutic objective in hypotension or shock is the maintenance of a flow of blood adequate to sustain the viability of such crucial organs as the liver, the kidney, the heart and the brain. While a minimal head of pressure is required for this purpose, particularly in the case of the heart and brain, the level required is apparently not large. In simple hypotension, the work required of the heart falls more rapidly than does coronary flow. There is a fair margin of safety in the cerebral circulation between the level of flow required to maintain normal consciousness, and that which will produce irreversible neuronal damage. We have already seen that in the case of the liver and kidney, vaso-constriction in the presence of an inadequate cardiac output jeopardizes rather than enhances the flow through these organs. As a matter of fact, even with a normal or elevated cardiac output, excessive vasoconstriction alone, if prolonged, may give rise to irreversible shock. Acute decerebration in animals is associated with a marked sympatho-adrenal discharge and within a few hours fatal shock develops. Shock can be prevented and survival greatly prolonged in such animals by sympathectomy or adrenergic blockade. Large infusions of pressor sympathomimetic amines alone will also precipitate shock in experimental animals, an outcome which can be prevented by

†More recently published studies have indicated that when bleeding is gradual, animals with adrenergic blockade require just as much blood loss to reach a given degree of hypotension and are not more sensitive to a given degree of blood loss. 
adrenergic blockade. It is well known that factors such as pain, cold, strong emotions and asphyxia, all of which tend to produce reflex vaso-constriction, also tend to potentiate the development of shock from haemorrhage or trauma, and for a given degree of fluid loss tend to make traumatic shock more severe than that due to simple haemorrhage alone. Experimentally it has been shown that this potentiation in the case of strong afferent stimuli can be prevented by blockade or interruption of the nervous pathways involved.

All of these considerations make conservative medical scientists very wary of claims for beneficial effects of sympathomimetic amines in shock, particularly where the condition is the result of loss of circulating blood, and where fairly intense reflex vaso-constriction is already present. In the case of hypotension due to primary vaso-dilatation (spinal anaesthesia, spinal shock, ganglionic blockade, certain types of central lesions, overwhelming sepsis), the use of moderate amounts of suitable vaso-pressor agents may be rational. Such patients are considerably more susceptible to blood loss than are persons with intact and functional vascular innervation. Also direct myocardial depression as in barbiturate poisoning may be assisted by sympathomimetic agents because of their direct cardiac actions. In most of these cases while probably not required for the prevention of irreversible shock, or as a life saving procedure, unless the hypotension is really profound, the restoration of normal blood pressure leads to a subjective improvement. The patient is more alert and feels more comfortable and treatment may prevent the nausea, malaise or impairment of consciousness which often accompanies hypotension. Similar immediate effects rnay be seen upon the administration of such agents to patients in shock with reduced blood volume, but here the crucial question is: What is the effect on survival? This question can only be adequately answered on the basis of carefully controlled clinical investigations, where individuals with comparable degrees of shock are compared. There are many clinical reports on the use of sympathomimetic agents in patients with shock. Some of these present apparently dramatic results. A recent report describes a patient with a case of perforated ulcer, in a profound state of shock with classical symptoms, who failed to respond to fluid replacement but responded beautifully to nor-epinephrine infusion. The nor-epinephrine had to be continued for over twenty-four hours before the blood pressure became self-supporting. Its use permitted an operation which otherwise would have been considered to be out of the question. However, this represents a single case. Single cases are never very impressive to a person familiar with the vagaries of biological material and the principles of statistical validity of data.

Unfortunately, all of the clinical reports thus far available consist entirely of small series of cases in which the system of controls leaves much to be desired. None that I know of involve any very sizeable group of comparable cases in which treated patients were alternated with controls. In controlled animal experiments, there is no evidence that mortality is reduced in traumatic or haemorrhagic shock as a result of the administration of sympathomimetic amines. In a recent review, Frank cites unpublished data showing that nor-epinephrine does not prolong survival in experimental haemorrbagic shock, and does not improve hepatic blood flow during shock.

Many of these same considerations apply to several recent reports advocating 
the use of sympathomimetic amines in the treatment of shock associated with myocardial infarction. The use of nor-epinephrine in this condition may seem paradoxical but it should be kept in mind that (1) all sympathomimetic agents increase coronary flow, (2) nor-epinephrine causes relatively little increase in cardiac irritability in animals with intact reflexes. The cause and nature of the shock which develops in myocardial infarction is still the subject of controversy. Some investigators claim that fluid loss occurs. Others deny this and claim that cardiac incompetence is primary. Others state that reflex vaso-dilatation is responsible. At any rate true shock in the presence of infarction is a very grave condition. It is not surprising that several of the reports of the use of sympathomimetic amines stress the production of successful pressor responses, but play down the relatively meagre survival value of the treatment. In all these reports, the treated cases are compared/with general statistics rather than with control cases whose comparability is determined. The pooled data from several such reports suggest survival of as many as $30^{\circ}$ to 40 per cent of patients presenting this syndrome treated with nor-epinephrine as compared with about 20 per cent in other types of therapy. For a difference in mortality of this magnitude, the number of cases as yet is rather small for any far-reaching conclusions. Incidentally, one group of workers employed mephenteramine (Wyamine) rather than nor-epinephrine. This and several other agents such as Neosynephrine possess properties which are very similar to nor-epinephrine. They differ primarily in requiring larger doses, having a longer duration of action, but developing tachyphylaxis (that is becoming relatively less effective with repeated or prolonged use).

The dramatic results seen in some instances suggest that in certain cases at least shock due to myocardial incompetence or reflex vaso-dilatation may be sufficiently profound to represent an acute threat to life, and that the actions of nor-epinephrine may aid in tiding the patient over this crisis.

In a recent discussion of this general problem, Dr. Mark Nickerson, an outstanding authority in the field of the pharmacology of the sympathetic nervous system, summed up his impression as follows: "I have been unable to find in the literature any report of controlled experiments in which any pressor agent administered in any dosage schedule in any type of shock, has improved the survival rate. I am forced to conclude that the available evidence fails to demonstrate any beneficial effect of vaso-constriction in protection against the development of irreversible shock."

This statement is debunking of a high order, and stresses the critical approach which the medical scientist must maintain toward new therapeutic claims. It points out that the case for these agents in the treatment of shock where reflex vaso-constriction is already present has not been proved. It does not disprove these claims, or preclude the possibility that further experiments and properly controlled clinical investigations will ultimately justify some of the hopes now placed in them. Some of the isolated clinical reports have been very suggestive. Nor-epinephrine has been studied far less extensively than epinephrine. The differences in action between these two drugs could conceivably provide a basis for some hope that nor-epinephrine may offer rational treatment in early shock 
due to fluid loss. For instance, nor-epinephrine is far less toxic than epinephrine, and much larger amounts are required to produce experimentally irreversible shock. Lands, who is associated with the company which produces nor-epinephrine, has suggested that whereas epinephrine dilates the extensive vascular bed of skeletal muscle and therefore diverts large amounts of blood to this relatively unimportant bed, it may further compromise flow to vital organs. The release of epinephrine from the adrenal medulla is an integral part of the sympatho-adrenal discharge which is set up by compensatory reflexes. Conceivably, the restoration of blood pressure by nor-epinephrine might relieve the drive to this discharge and therefore reduce epinephrine release. Further, by closing down skeletal muscle vessels as well, the vital visceral organs may be placed in a better position to compete for a larger share of the available cardiac output. As yet we know very little of the effects of nor-epinephrine on specific vital vascular beds (such as the liver). These points remain to be decided by future studies, both experimental and clinical, before the degree of confidence which can be placed in this type of therapy will be apparent. We do not know whether nor-epinephrine can be of assistance in overcoming shock when the "irreversible" stage has been reached, or whether any beneficial actions which it can be expected to exert will be useful only if applied early in the condition before irreversibility develops. We cannot as yet be sure that such therapy may not actually be harmful rather than beneficial to some patients. I would suggest therefore that its use be reserved for clinical investigation or for patients who are in profound shock, who fail to respond to extensive fluid replacement or other therapeutic procedures, and whose prognosis is therefore very grave under any circumstances.

\section{SUMMARY}

1. The salient features of the various conditions grouped under the heading of "shock" have been briefly considered. Broadly speaking, the principal feature which these conditions share in common is a persistent hypotension the proximate cause of which may be either cardiac or peripheral.

2. The action of the sympathomimetic amines on the cardiac, and peripheral vascular mechanisms has been discussed, with particular reference to epinephrine and nor-epinephrine.

3. On the basis of the present experimental evidence we cannot as yet be sure that the use of sympathomimetic amines in the treatment of shock may not be actually harmful rather than beneficial to some patients. It is suggested, therefore, that its use be reserved for clinical investigation, or for patients who are in profound shock, who fail to respond to extensive fluid replacement or other therapeutic procedures, and whose prognosis therefore is very grave under any circumstances.

\section{RÉSUMÉ}

Toute discussion au sujet du traitement par l'emploi de drogues doit nécessairement reposer sur deux questions-1) Quelle est la nature du délabrement à traiter? et 2) Jusqu’à quel point peut-on atteindre les buts médicamenteux par 
l'emploi des outils disponibles de pharmacollogie? Ces principes peuvent sembler évidents en soi et cependant l'étendue de notre ignorance sur ces deux questions nous oblige souvent à nous reposer, pour le traitement, sur des principes plutôt empiriques que rationnels. Pendant les cinq dernières années on a constaté un nombre de progrès importants dans la pharmacologie du système grand sympathique avec l'introduction d'agents dont le rôle reste encore à être complèțement vérifié.

Parmi les agents sympathomimétiques la nor-épinéphrine a sans doute attiré plus d'attention que tout autre. L'intérêt renouvelé pour ce composé suit la découverte qu’il est fabriqué dans le corps et qu'il est le principal médiateur de l'activité du système sympathique, comprenant $80 \%$ ou plus de la substance libérée par l'excitation du système sympathique, le reste étant l'épinéphrine. Ces deux substances sont aussi présentes dans la sécrétion de la médullo-surrénale, mais leurs proportions relatives sont inversées.

L'action de l'épinéphrine sur les vaisseaux périphériques est complexe. Quoique les vaisseaux de la peau et de la loge splanchnique soient très resserrés, cette action est compensée par la dilatation des vaisseaux des muscles squelettiques, de sorte que la résistance totale périphérique est relativement inchangée. Par conséquent les actions excitatrices cardiaques sont principalement responsables de la réponse-hypertenseur lorsque l'épinéphrine est administrée.

L'action vaso-constrictive de la nor-épinéphrine est plus uniforme. Ses actions vaso-dilatatrices sont secondaires et son effet d'ensemble est principalement vasoconstricteur, avec une augmentation de la résistance périphérique totale. Son action excitatrice cardiaque est mitigée en grande partie chez les patients intacts par des réflexes provenant des presso-récepteurs, ce qui mène à une bradycardie par raisons des efférents vagues au coeur.

Une évaluation de l'efficacité possible des agents sympathomimétiques dans le traitement du choc exige un examen des aspects saillants des états groupés sous le titre choc. L'aspect important caractérisant tous ces états est une hypotension persistante, dont la cause immédiate peut être périphérique ou cardiaque. La méthode raisonnable et évidente dans ce cas est de songer à des moyens d'augmenter la pression artérielle. L'emploi de drogues vaso-constrictrices s'offre comme moyen commode d'aboutir à cette fin. Mais la pression artérielle lest-elle une mesure sûre de la sufficance circulatoire? La responsabilité cruciale de la circulation est de fournir l'oxygène et la nourriture aux tissus. Son habileté à accomplir cette tâche dépend du taux du flux sanguin à travers la circulation périphérique qui est une fonction non seulement de la pression mais aussi de la résistance périphérique offerte par les petits vaisseaux sanguins. L'hypotension produite par la dilatation périphérique peut bien être tolérée parce que la résistance périphérique est basse et le flux sanguin est bien maintenu. Contrairement à cette situation le choc peut provenir d'une réduction prononcée du volume de sang en circulation causant un faible retour veineux, un faible chargement cardiaque et une diminution du débit du coeur. Dans ce cas la vaso-constriction compensatrice est assez forte et la pression artérielle est souvent maintenue à des niveaux assez normaux tandis que le taux du flux sanguin à travers les tissus est réduit. Si dans ces cas des pressions artérielles aussi basses que $30-40 \mathrm{~mm} \mathrm{Hg}$ 
persistent, le choc devient irréversible. Ce n'est pas la basse pression artérielle qui rend le choc irréversible mais la réduction du taux du flux sanguin à travers les organes vitaux.

Ces faits nous obligent à reconnaître que le but raisonnable du traitement de l'hypotension ou choc est le maintien d'un flux sanguin suffisant pour conserver la vitalité des organes vitaux. Quoique ce but exige une tête de pression minimale, le niveau manifestement n'est pas élevé. Dans le cas d'hypotension simple, l'effort requis du coeur décroît plus rapidement que l'écoulement sanguin. Une vaso-constriction excessive, même en présence d'un débit cardiaque normal ou élevé peut amener un choc irréversible. Comme on sait des facteurs tels la douleur, le froid, de fortes émotions et l'asphyxie qui tendent tous à produire une vaso-constriction réllexe, tendent aussi à amener le choc d'une condition d'hémoragie ou de trauma.

Toutes ces considérations mettent les savants médicaux prudents sur leur garde concernant les affirmations que les amines sympathomimétiques ont des effets salutaires dans le traitement du choc. Nous ne pouvons pas encore être sûrs qu'un tel traitement n'est pas en fait nuisible plutôt que salutaire pour certains patients. Je propose donc que son emploi soit restreint à des essais de clinique ou à des patients subissant un choc profond qui ne répondent pas à un remplacement hydrique prolongé ou autres traitements et dont le pronostic en tout cas est par conséquent très grave.

\section{REFERENCES}

I. SHOCK:

1. Wiggers, C. J. Physiology of Shock. Commonwealth Fund, 1950.

2. ZwEIFACH, B. W. Ann. New York Acad. Sc. 55:370 (1952).

3. Frank, H. A. Medical Progress: Present Day Concepts of Shock. New England J. Med. 248:445 (1953).

4. Shock and Circulatory Homeostasis. Vols. I and II. Macy Foundation, 1951, 1952.

II. Cunnical Use of Sympathomimetics in Shock:

1. Moyer, J. H., Skelton, J. M. \& Mills, L. C. Nor-epinephrine: Effect in Normal Subjects; Use in Treatment of Shock Unresponsive to Other Measures. Am. J. Med. 15:330 (1953).

2. Gootnick, A. \& KNox, F. H. Management of \$hock in Acute Myocardial Infarction. Circulation 7:511 (1953).

3. Calenda, D. G., Uricchio, J. F. \& Friedman, L. M. The Management of the Shock of Myocardial Infarction with 1-Norepinephrine. Am. J. M Sc. 226:399 (1953).

4. Braude, A. I., Williams, D., Siemenski, J. \& Murphy, R. Shock-Like State due to Transfusion of Blood Contaminated with Gram-negative Bacilli. Arch. Int. Med. 92:75 (1953).

5. Kurland, G. S. \& Malach, M. The Clinical Use of Nor-Epinephrine in the Treatment of Shock Accompanying Myocardial Infarction and Other Conditions. New England J. Med. $247: 383$ (1952).

6. Miller, A. J. \& Baker, L. A. Arterenol (Levophed) in Treatment of Shock due to Acute Myocardial Infarction. Arch. Ift. Med. 89:491 (1952).

7. Helcenstein, H. K., Brofman, B. L. \& Caskex, W. H. Shock Accompanying Myocardial Infarction: Treatment with Pressor Amines. Am. Heart J. 44:407 (1952).

8. Luger, N. M., Klumin, A. \& Fremont, R. A. Treatment of Shock with Arterenol. J.A.M.A. 146:1592 (1951). 